\title{
Protecting protein against ruminal degradation could contribute to reduced methane production
}

\author{
Andrés N. Haro ～María Dolores Carro | Trinidad de Evan ｜ Javier González
}

\begin{abstract}
Ruminants have a low efficiency of nitrogen $(\mathrm{N})$ utilization that has negative implications for animal production and the environment, but reducing the ruminal degradation of protein can help to reduce $\mathrm{N}$ losses. The objective of this study was to evaluate the inclusion of sunflower meal (SM) and sunflower seed (SS) protected against ruminal degradation in high-cereal diets on in vitro ruminal fermentation and $\mathrm{CH}_{4}$ production. Samples of SS and SM were sprayed with a solution of malic acid $1 \mathrm{M}(400 \mathrm{ml} /$ $\mathrm{kg}$ sample) and dried at $150^{\circ} \mathrm{C}$ for $1 \mathrm{hr}$ as a protective treatment. Four diets were formulated to contain either 13 (low) or 17 (high) g of crude protein (CP)/100 g dry matter (DM), and included SM and SS either untreated (13CON and 17CON diets) or treated as before described (13TR and 17TR diets). Diets were incubated in vitro with rumen fluid from sheep for 8 and 24 hr. The treatment did not affect $(p \geq 0.57)$ total volatile fatty acid (VFA) production at any incubation time, but it reduced $(p<0.05$ ) $\mathrm{NH}_{3}-\mathrm{N}$ concentrations by 19.2 and $12.5 \%$ at 8 and $24 \mathrm{hr}$ respectively. Both $\mathrm{CH}_{4}$ production and $\mathrm{CH}_{4} /$ VFA ratio were lower $(p<0.02)$ in TR than in CON diets at $8 \mathrm{hr}$, but differences disappeared $(p>0.05)$ at $24 \mathrm{hr}$. The treatment increased the molar proportion of propionate $(p=0.001)$ and reduced that of isovalerate $(p=0.03)$ at $8 \mathrm{hr}$ compared with CON diets, but only a reduction of isovalerate proportion $(p=0.03)$ was detected at $24 \mathrm{hr}$. There were no treatment $x$ crude protein level interactions $(p>0.05)$ in any parameter, but high-protein diets had greater $\mathrm{NH}_{3}-\mathrm{N}$ concentrations $(p<0.001)$ and lower VFA production $(p<0.001)$ than low-protein diets at $24 \mathrm{hr}$. The treatment reduced protein degradation, and $\mathrm{CH}_{4}$ production was decreased by 4.6 and $10.8 \%$ for low- and high-protein diets, respectively, at short incubation times without affecting VFA production, thus improving fermentation efficiency and decreasing polluting emissions.
\end{abstract}

KEYWORDS

in vitro fermentation, methane, protein protection, sunflower meal, sunflower seed

\section{1 | INTRODUCTION}

Methane production in the rumen is a major concern worldwide due to its contribution to global warming. Dietary characteristics are one of the most important factors influencing $\mathrm{CH}_{4}$ production, and it is well known that diets rich in structural carbohydrates yield higher $\mathrm{CH}_{4}$ emissions compared with those high in nonstructural carbohydrates (Kumar et al., 2014). A recent in vitro study (Vanegas, González, \& Carro, 2017) showed the generation of $\mathrm{CH}_{4}$ from pure protein fermentation and that the response in 
$\mathrm{CH}_{4}$ production to protein supply differed with the basal substrate, being higher for a rapidly fermented substrate than for a slowly fermented one. In addition, the protection of sunflower protein against ruminal degradation by a combined treatment of malic acid and heat resulted in a reduction of in vitro $\mathrm{CH}_{4}$ production that was attributed to reduced protein degradation (Vanegas, Carro, Alvir, \& González, 2017; Vanegas, González, Alvir, \& Carro, 2017). To our best knowledge the influence of including rumen-protected protein in diets representative of those fed in the practice on $\mathrm{CH}_{4}$ production has not yet been investigated. The objective of this study was therefore to evaluate the inclusion of rumen-protected sunflower meal (SM) and sunflower seed (SS) in high-cereal diets on in vitro $\mathrm{CH}_{4}$ production and ruminal fermentation. Both SM and $\mathrm{SS}$ are protein sources extensively used in practical feeding of ruminants, and a reduction in their ruminal protein degradation could increase protein utilization by the animal and reduce $\mathrm{N}$ environmental emissions.

\section{MATERIALS AND METHODS}

Samples (500 g) of both SM and SS were ground $(2 \mathrm{~mm})$, weighed and sprayed with a solution of $1 \mathrm{M}$ malic acid at a rate of $400 \mathrm{ml}$ per $\mathrm{kg}$ of substrate fresh matter, left at room temperature for $1 \mathrm{hr}$ and subsequently dried at $150^{\circ} \mathrm{C}$ for $1 \mathrm{hr}$ as a protective treatment (TR) against ruminal degradation (Vanegas, González, Alvir, et al., 2017). Four total mixed diets were formulated according to a $2 \times 2$ factorial arrangement of treatments. The diets had 13 (low) or 17 (high) g of crude protein (CP)/100 g dry matter (DM) and included SM and SS either untreated (13CON and 17CON diets) or treated as before described (13TR and 17TR diets). All feed ingredients were ground to pass a $1 \mathrm{~mm}$ screen and mixed. Ingredient and chemical composition of diets and chemical composition of SM and SS are shown in Table 1. Dry matter, ash, nitrogen and ether extract contents were determined according to the Association of Official Analytical Chemists (1999). Organic matter content was calculated as 100 minus ash content. Neutral detergent fibre (NDF), acid detergent fibre (ADF) and acid detergent lignin (ADL) analyses were performed as described by Van Soest, Robertson, and Lewis (1991). Sodium sulphite and heatstable amylase were used in the sequential analysis of NDF, ADF and $A D L$, and they were expressed exclusive of residual ash.

Four sheep $(67.2 \mathrm{~kg} \pm 2.31 \mathrm{~kg}$ body weight), each provided with a permanent rumen cannula, were used as rumen fluid donors for the in vitro incubations. Sheep were fed a mixed diet of grass hay and a commercial concentrate (1:1) at a daily rate of $42 \mathrm{~g} / \mathrm{kg}$ body weight ${ }^{0.75}$ distributed in two equal meals. Animals were managed

TABLE 1 Chemical composition and ingredients of experimental diets used as substrates for in vitro incubations and chemical composition of sunflower seed and sunflower meal either untreated (CON) or treated (TR) to protect the protein against ruminal degradation

\begin{tabular}{|c|c|c|c|c|c|c|c|c|}
\hline \multirow[b]{2}{*}{ Item } & \multicolumn{4}{|c|}{ Experimental diets ${ }^{a}$} & \multicolumn{2}{|c|}{ Sunflower seed ${ }^{b}$} & \multicolumn{2}{|c|}{ Sunflower meal ${ }^{\mathbf{b}}$} \\
\hline & $13 \mathrm{CON}$ & 13TR & $17 \mathrm{CON}$ & 17TR & $\mathrm{CON}$ & TR & $\mathrm{CON}$ & TR \\
\hline Organic matter ${ }^{c}$ & 961 & 960 & 952 & 951 & 969 & 970 & 927 & 932 \\
\hline Crude protein & 131 & 130 & 170 & 169 & 179 & 171 & 359 & 337 \\
\hline Acid detergent fibre & 127 & 125 & 165 & 166 & 159 & 147 & 275 & 261 \\
\hline Acid detergent lignin & 26.2 & 25.6 & 39.0 & 40.2 & 53.8 & 48.7 & 88.2 & 84.5 \\
\hline Ether extract & 85.3 & 85.7 & 83.7 & 85.3 & 467 & 459 & 12.9 & 20.2 \\
\hline $\begin{array}{l}\text { Non-structural } \\
\text { carbohydrates }^{\mathrm{d}}\end{array}$ & 420 & 422 & 329 & 331 & 31.9 & 69.0 & 65.1 & 109 \\
\hline Maize grains & 156 & 155 & 116 & 110 & & & & \\
\hline Straw & 150 & 150 & 150 & 150 & & & & \\
\hline CON-sunflower seed & 150 & - & 150 & - & & & & \\
\hline TR-sunflower seed & - & 153 & - & 153 & & & & \\
\hline CON-sunflower meal & 75.0 & - & 235 & - & & & & \\
\hline TR-sunflower meal & - & 79.6 & - & 259 & & & & \\
\hline
\end{tabular}

a 13CON, 13TR, 17CON and 17TR: Diets with two levels of crude protein (130 and $170 \mathrm{~g} / \mathrm{kg}$ dry matter) and containing either untreated (CON) or treated (TR) sunflower seed and sunflower meal to protect protein against ruminal degradation. ${ }^{b}$ Sunflower seed and meal were either untreated (CON) or treated with a solution $1 \mathrm{M}$ malic acid $\left(400 \mathrm{ml} / \mathrm{kg}\right.$ ) and dried at $150^{\circ} \mathrm{C}$ for $1 \mathrm{hr}$ to protect protein against ruminal degradation (TR). ${ }^{\circ} \mathrm{Calculated}$ as 1000 - ash. ${ }^{d}$ Calculated as 1000 - (ash + crude protein + neutral detergent fibre + ether extract). ${ }^{\mathrm{C}} \mathrm{A}$ wheat variety with greater starch and lower protein than hard wheat. 
in accordance with the Spanish guidelines for experimental animal protection (Royal Decree 53/2013 of February 1st on the protection of animals used for experimentation or other scientific purposes) in line with European legislation (Directive 2010/63/UE), and experimental procedures were approved by the Animal Experimentation Ethics Committee of the Comunidad Autónoma de Madrid (Approval number PROEX 035/17).

Samples ( $300 \mathrm{mg}$ DM) of each diet were accurately weighed into glass vials ( $115 \mathrm{ml})$. Ruminal contents from each sheep were obtained immediately before the morning feeding, strained through 4 layers of cheesecloth and the fluid mixed with a culture medium (1:4 ratio; $\mathrm{vol} / \mathrm{vol})$ at $39^{\circ} \mathrm{C}$. The medium of Goering and Van Soest (1970) was changed by replacing the $\left(\mathrm{NH}_{4}\right) \mathrm{HCO}_{3}$ with $\mathrm{NaHCO}_{3}$ and excluding the trypticase to obtain a $\mathrm{N}$-free medium. Each vial was filled with $30 \mathrm{ml}$ of the mixture under $\mathrm{CO}_{2}$ flushing before being capped and incubated at $39^{\circ} \mathrm{C}$. For each diet, a total of 16 vials were incubated, four with the ruminal fluid from each sheep (inoculum); therefore, there were four replicates per experimental treatment and sampling time. After $8 \mathrm{hr}$ of incubation, gas production was determined in 2 vials per diet and inoculum using a pressure transducer (Wider eager Wide Range Pressure Meter; Sper Scientific LTD, Scottsdale, AZ, USA) and a plastic syringe. A gas sample $(15 \mathrm{ml})$ was removed from each vial and stored in a vacuum airtight tube (Terumo Europe N.V., Leuven, Belgium) until $\mathrm{CH}_{4}$ analysis by gas chromatography according to Martínez, Ranilla, Tejido, Ramos, and Carro (2010). Vials were uncapped, the $\mathrm{pH}$ was measured (Crison Basic $20 \mathrm{pHmeter,} \mathrm{Crisson}$ Instruments, Barcelona, Spain) and $5 \mathrm{ml}$ of vials content were added to $5 \mathrm{ml}$ of $0.5 \mathrm{M} \mathrm{HCl}$ and kept frozen $\left(-20^{\circ} \mathrm{C}\right)$ until volatile fatty acid (VFA) and $\mathrm{NH}_{3}-\mathrm{N}$ analysis following the procedures described by Ranilla, Carro, López, Newbold, and Wallace (2001). The rest of the vials were processed as before described after $24 \mathrm{hr}$ of incubation.

At each incubation time, data from the 2 vials incubated for each diet and inoculum were averaged before statistical analysis ( 4 values for each diet). The amount of organic matter apparently fermented (OMAF) in each vial was calculated from VFA production following the equation proposed by Demeyer (1991): OMAF $(\mathrm{mg})=162 \times[\mu \mathrm{mol}$ acetate $/ 2)+(\mu \mathrm{mol}$ propionate $/ 2)+\mu \mathrm{mol}$ butyr ate]. Data for each incubation time were analysed independently as a factorial model using the PROC MIXED of SAS (SAS Institute Inc, 2012). The effects of treatment, $C P$ level and the treatment $\times C P$ level interaction were considered fixed, and inoculum effect was considered random. Significance was declared at $p<0.05$ and $p$ values between 0.05 and 0.10 were considered as a trend.

\section{I RESULTS AND DISCUSSION}

The combined malic acid heat treatment was selected because its efficacy for protecting protein from ruminal degradation was proved in previous in situ and in vitro studies (Arroyo et al., 2011, 2013; DíazRoyón, Arroyo, Sánchez, \& González, 2016; Vanegas, González, Alvir, et al., 2017; Vanegas, Carro, et al., 2017). Malic acid, as other acids, causes denaturation of proteins, reduces its solubility and provides effective protection against degradation by ruminal microorganisms. The treatment caused only minor changes in chemical composition of both SS and SM (Table 1), and the slight decreases observed in $C P, N D F, A D F$ and $A D L$ content in TR samples compared with the untreated samples might be due to a dilution effect associated with adding malic acid in the treatment.

The experimental diets were formulated to contain a high proportion of cereal grains ( 62.2 and $45.2 \%$ for low- and high-protein diets respectively) because Vanegas, González, et al. (2017) observed that the contribution of protein fermentation to $\mathrm{CH}_{4}$ production was greater with a rapidly fermentable substrate (starch) than with a slowly fermentable substrate (cellulose). Diets with two different CP levels were formulated to analyse the possible interaction between treatment and $\mathrm{CP}$ level. Finally, the study examined the differences between diets at two incubation times ( 8 and $24 \mathrm{hr}$ ), as sunflower protein is rapidly degraded in the rumen (Arroyo et al., 2013) and the influence of treatment might become less marked as incubation time increased.

There were no effects $(p>0.05)$ of either treatment or CP level on final $\mathrm{pH}$ (values ranged from 7.02 to 7.08 , and from 6.63 to 6.71 at 8 and $24 \mathrm{hr}$ of incubation respectively). As shown in Table 2, no treatment $\times \mathrm{CP}$ level interactions were observed for any determined parameter, excepting a trend for $\mathrm{CH}_{4}$ /total VFA ratio at $8 \mathrm{hr}$ incubation $(p=0.09)$ and for total VFA at $24 \mathrm{hr}(p=0.088)$. After $8 \mathrm{hr}$ incubation, the fermentation of diets including rumen-protected $\mathrm{SS}$ and SM resulted in lower $\mathrm{NH}_{3}-\mathrm{N}$ concentration ( $p=0.01$ ) compared with CON diets, which is consistent with the hypothesis that treatment reduced sunflower protein degradation. The lower proportions of isovalerate and valerate observed in TR diets also suggest a reduction of protein degradation, as these VFA are only generated in the degradation of branched-chain amino acids (Wallace $\&$ Cotta, 1988).

Fermentation of TR diets produced lower $\mathrm{CH}_{4}$ production $(p=0.02)$ compared with CON diets, but total VFA was similar $(p=0.57)$. The lack of differences in total VFA production indicates that the treatment of SS and SM did not negatively affect their DM fermentation, and that the reduced $\mathrm{CH}_{4}$ production observed in TR diets was not a consequence of lower diet fermentability. In fact, there were no differences $(p=0.59)$ between TR and CON diets in the estimated amount of OMAF. Previous in vitro studies with protein as the only substrate (Vanegas, González, et al. (2017)) or replacing non-protein $\mathrm{N}$ with protein- $\mathrm{N}$ with different substrates (Carro, López, Valdés, \& González, 1999; Vanegas, González, et al. (2017)) showed that $\mathrm{CH}_{4}$ generation in ruminal fermentation was partly due to protein degradation, presumably due to the hydrogen generation in the fermentation of carbon skeletons resulting from amino acid deamination. Values of $\mathrm{NH}_{3}-\mathrm{N}$ concentrations and those of $\mathrm{CH}_{4}$ production at both incubation times were positively correlated $(p<0.001)$ for both low-protein $(r=0.797 ; n=16)$ and high-protein $(r=0.892 ; n=16)$ diets. A positive relationship between $\mathrm{NH}_{3}-\mathrm{N}$ and $\mathrm{CH}_{4}$ may just reflect different amounts of organic matter fermented in the vials, but in this study there were no differences in the OMAF between CON and TR diets; therefore, it seems that the lower $\mathrm{CH}_{4}$ production observed for TR diets was due to the reduction in protein degradation. 
TABLE 2 In vitro ruminal fermentation of diets containing sunflower seed and sunflower meal, either untreated (CON) or treated (TR) against ruminal degradation, and two crude protein levels after 8 and $24 \mathrm{hr}$ of incubation

\begin{tabular}{|c|c|c|c|c|c|c|c|c|}
\hline \multirow[b]{2}{*}{$\begin{array}{l}\text { Incubation time and } \\
\text { item }\end{array}$} & \multicolumn{4}{|c|}{ Experimental diets $\mathrm{s}^{\mathrm{a}}$} & \multirow[b]{2}{*}{ SEM } & \multicolumn{3}{|l|}{$p$ value } \\
\hline & $13 \mathrm{CON}$ & 13TR & $17 C O N$ & 17TR & & TR & $\begin{array}{l}\text { Crude protein } \\
\text { level }\end{array}$ & $\begin{array}{l}\text { TR } \times \text { Crude } \\
\text { protein level }\end{array}$ \\
\hline \multicolumn{9}{|l|}{$8 \mathrm{hr}$} \\
\hline Gas (ml) & 30.7 & 31.7 & 27.2 & 27.5 & 1.85 & 0.75 & 0.07 & 0.86 \\
\hline $\mathrm{CH}_{4}(\mathrm{ml})$ & 1.53 & 1.46 & 1.67 & 1.49 & 0.045 & 0.02 & 0.09 & 0.26 \\
\hline $\begin{array}{l}\text { Total volatile fatty } \\
\text { acid (VFA; mmol) }\end{array}$ & 0.421 & 0.421 & 0.443 & 0.427 & 0.0138 & 0.57 & 0.33 & 0.59 \\
\hline \multicolumn{9}{|c|}{ Individual VFA (mol/100 mol) } \\
\hline Acetate & 51.4 & 51.2 & 52.8 & 51.3 & 0.57 & 0.18 & 0.22 & 0.28 \\
\hline Propionate & 31.9 & 33.0 & 31.0 & 33.2 & 0.34 & 0.001 & 0.30 & 0.14 \\
\hline Isovalerate & 1.34 & 1.10 & 1.46 & 1.19 & 0.099 & 0.03 & 0.32 & 0.90 \\
\hline Valerate & 2.34 & 2.19 & 2.29 & 2.14 & 0.072 & 0.07 & 0.52 & 0.99 \\
\hline $\begin{array}{l}\text { Acetate/propionate } \\
\text { (Ac/Pr; } \mathrm{mol} / \mathrm{mol} \text { ) }\end{array}$ & 1.64 & 1.58 & 1.73 & 1.57 & 0.033 & 0.009 & 0.21 & 0.16 \\
\hline $\mathrm{CH}_{4} / \mathrm{VFA}(\mathrm{ml} / \mathrm{mmol})$ & 3.66 & 3.52 & 3.87 & 3.55 & 0.040 & 0.001 & 0.03 & 0.09 \\
\hline OMAF $(\mathrm{mg})^{\mathrm{b}}$ & 37.1 & 37.0 & 38.7 & 37.5 & 1.17 & 0.59 & 0.39 & 0.61 \\
\hline \multicolumn{9}{|l|}{$24 \mathrm{hr}$} \\
\hline Gas (ml) & 56.3 & 55.5 & 57.7 & 58.3 & 3.29 & 0.98 & 0.55 & 0.84 \\
\hline $\mathrm{CH}_{4}(\mathrm{ml})$ & 5.68 & 5.53 & 5.05 & 5.13 & 0.125 & 0.80 & 0.003 & 0.39 \\
\hline Isobutyrate & 1.55 & 1.55 & 1.88 & 2.02 & 0.100 & 0.47 & 0.003 & 0.51 \\
\hline Isovalerate & 1.85 & 1.72 & 2.28 & 2.07 & 0.068 & 0.03 & $<0.001$ & 0.59 \\
\hline Valerate & 1.94 & 1.90 & 2.26 & 2.14 & 0.069 & 0.26 & 0.003 & 0.59 \\
\hline $\mathrm{Ac} / \operatorname{Pr}(\mathrm{mol} / \mathrm{mol})$ & 2.17 & 2.16 & 2.20 & 2.21 & 0.057 & 0.98 & 0.48 & 0.91 \\
\hline $\mathrm{CH}_{4} / \mathrm{VFA}(\mathrm{ml} / \mathrm{mmol})$ & 4.92 & 4.92 & 4.96 & 4.88 & 0.071 & 0.54 & 0.99 & 0.52 \\
\hline OMAF $(\mathrm{mg})^{\mathrm{b}}$ & 103 & 99.9 & 89.8 & 92.1 & 1.43 & 0.81 & $<0.001$ & 0.10 \\
\hline
\end{tabular}

a 13CON, 13TR, 17CON and 17TR: Diets with two levels of crude protein (130 and $170 \mathrm{~g} / \mathrm{kg}$ dry matter) and containing either untreated (CON) or treated (TR) sunflower seed and sunflower meal to protect protein against ruminal degradation. Each culture contained $300 \mathrm{mg}$ of diet dry matter.

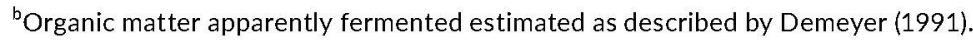

The ratio $\mathrm{CH}_{4}$ /VFA can be used as an indicator of the efficiency of ruminal fermentation, as $\mathrm{CH}_{4}$ represents an energy loss and VFA are the main energy source for the host animal and are also precursors for the synthesis of fatty acids and glucose. In agreement with a previous study in which providing protein- $\mathrm{N}$ to in vitro cultures of ruminal microorganisms containing a rapidly fermented substrate enhanced $\mathrm{CH}_{4} / \mathrm{VFA}$ ratio (Vanegas, González, et al. (2017)). CON-diets showed greater $\mathrm{CH}_{4}$ /VFA ratios $(p=0.001)$ than TR diets at $8 \mathrm{hr}$ incubation, thus indicating a more efficient fermentation in TR diets. In addition, fermentation of TR diets resulted in increased propionate proportion ( $p=0.001$ ) and reduced isovalerate proportion ( $p=0.03$ ) Different in vitro studies (Carro \& Ranilla, 2003; Tejido, Ranilla, García-Martínez, \& Carro, 2005) have reported that malate supplementation increased propionate production, which can contribute to a reduction in $\mathrm{CH}_{4}$ production, as malate acts as an electron acceptor and is converted to propionate by the succinate pathway. In contrast to that observed at $8 \mathrm{hr}$ of incubation, 
no effects of treatment ( $p=0.18$ to 0.98 ) were detected at $24 \mathrm{hr}$, with the exception of a reduction in both $\mathrm{NH}_{3}-\mathrm{N}$ concentrations $(p=0.002)$ and molar proportion of isovalerate $(p=0.03)$. As before discussed, these differences would indicate lower protein degradation in TR compared with CON diets. The reduction in $\mathrm{NH}_{3}-\mathrm{N}$ concentrations for TR diets, relative to those in CONdiets, was 19.2 and $12.6 \%$ at 8 and 24 hr, respectively (values averaged across CP levels), which indicates that protein protection was reduced with time, probably as a consequence of the continuous proteolytic activity of ruminal microbes.

There were no differences between high- and low-protein diets at $8 \mathrm{hr}$ incubation, with the exception of greater $\mathrm{CH}_{4} /$ VFA ratios $(p=0.03 ; 3.71$ vs. $3.59 \mathrm{ml} / \mathrm{mmol})$ and a trend $(p<0.10)$ to lower gas production (27.4 vs. $31.2 \mathrm{ml}$ ) and to greater $\mathrm{CH}_{4}$ production (1.58 vs. $1.50 \mathrm{ml}$ ) and $\mathrm{NH}_{3}-\mathrm{N}$ concentrations (77.6 vs. $70.2 \mathrm{mg} / \mathrm{l})$ for high-protein diets than for low-protein ones. This would indicate that the substitution of cereal grains (wheat and maize) by SM to reach $170 \mathrm{~g} \mathrm{CP} / \mathrm{kg}$ in high-protein diets resulted in lower fermentation efficiency at $8 \mathrm{hr}$ of incubation. After $24 \mathrm{hr}$ of incubation, both $\mathrm{CH}_{4}$ and VFA production were lower $(p=0.003$ and 0.001 respectively) for high compared with low-protein diets, resulting in a lower amount of OMAF for the high-protein diets ( $p<0.001 ; 91$ vs. $101 \mathrm{mg}$ ). Ruminal fermentation of CP generates less $\mathrm{CH}_{4}$ than carbohydrates (Jentsch et al., 2007), which could help to explain the lower $\mathrm{CH}_{4}$ production observed for highprotein diets at $24 \mathrm{hr}$ as these diets contained less carbohydrates $(698 \mathrm{~g} / \mathrm{kg}$ ) and more CP than low-protein diets (745 g of total carbohydrates $/ \mathrm{kg}$; Table 1). The trend to greater $\mathrm{CH}_{4}$ production observed at $8 \mathrm{hr}$ for high-protein compared with low-protein diets is difficult to explain, but could be related to greater CP degradation in these diets resulting in greater fermentation of carbon skeletons generated from amino acid deamination. This hypothesis is supported by the trend to increased $\mathrm{NH}_{3}-\mathrm{N}$ concentrations in high-protein diets.

In conclusion, the inclusion of sunflower seeds and sunflower meal treated with a combined malic acid-heat treatment in highcereal diets resulted in lower in vitro $\mathrm{CH}_{4}$ and $\mathrm{NH}_{3}-\mathrm{N}$ production at early stages of fermentation without decreasing the amount of organic matter apparently fermented. The results showed a greater fermentation efficiency of diets including rumen-protected sunflower feeds at $8 \mathrm{hr}$ of incubation, as indicated by the lower $\mathrm{CH}_{4} /$ VFA and acetate/propionate ratios than for diets with unprotected protein. The inclusion of rumen-protected sunflower feeds in the diet to reach CP contents of either 130 or $170 \mathrm{~g} / \mathrm{kg}$ DM did not affect negatively the in vitro fermentation of diets. If the efficacy of this treatment is confirmed in vivo, it could be a means of reducing both $\mathrm{N}$ and $\mathrm{CH}_{4}$ emissions.

\section{ACKNOWLEDGEMENTS}

Funding from the Spanish Ministry of Economy and Competitiveness (Project AGL2012-31064) and the Comunidad Autónoma de Madrid (CAM; Project MEDGAN ABI-2913) is gratefully acknowledged.

\section{ORCID}

Maria Dolores Carro (D) http://orcid.org/0000-0002-4221-9057

\section{REFERENCES}

Arroyo, J. M., González, J., Muñoz, J., Alvir, M. R., Rodríguez, C. R., lbáñez, M. A., \& del Castillo, M. D. (2011). In vitro efficiency of combined acid-heat treatments for protecting sunflower meal proteins against ruminal degradation. Animal, 5, 1988-1994. https://doi.org/10.1017/ S1751731111000279

Arroyo, J. M., González, J., Ouarti, M., Silván, J. M., del Castillo, M. R., \& de la Peña Moreno, F. (2013). Malic acid or orthophosphoric acid-heat treatments for protecting sunflower (Helianthus annuus) meal proteins against ruminal degradation and increasing intestinal amino acid supply. Animal, 7, 223-231. https://doi.org/10.1017/ S1751731112001292

Association of Official Analytical Chemists. (1999). Official methods of analysis, 16th edn. 5th rev. Gaithersburg, MD: Association of Official Analytical Chemists International.

Carro, M. D., López, S., Valdés, C., \& González, J. S. (1999). Effect of nitrogen form (casein and urea) on the in vitro degradation of cell walls from six forages. Journal of Animal Physiology and Animal Nutrition, 81, 212-222. https://doi. org/10.1046/j.1439-0396.1999.00231.x

Carro, M. D., \& Ranilla, M. J. (2003). Effect of the addition of malate on in vitro rumen fermentation of cereal grains. British Journal of Nutrition, 89, 181-188. https://doi.org/10.1079/BJN2002759

Demeyer, D. I. (1991). Quantitative aspects of microbial metabolism in the rumen and hindgut. In J. P. Jouany (Ed.), Rumen microbial metabolism and ruminant digestion (pp. 217-237). INRA Editions: Paris, France.

Díaz-Royón, F., Arroyo, J. M., Sánchez, M. D., \& González, J. (2016). Sunflower meal and spring pea ruminal degradation protection using malic acid or orthophosphoric acid-heat treatments. Animal Production Science, 56, 2029-2038. https://doi.org/10.1071/ AN14669

Goering, M. K., \& Van Soest, P. J. (1970). Forage fiber analysis (apparatus, reagents, procedures and some applications). Agricultural Handbook, no. 379. Washington DC, USA: Agricultural Research Services, USDA.

Jentsch, W., Schweigel, M., Weissbach, F., Scholze, H., Pittroff, W., \& Derno, M. (2007). Methane production in cattle calculated by the nutrient composition of the diet. Archives of Animal Nutrition, 61, 10-19. https://doi.org//10.1080/17450390601106580

Kumar, S., Choudhury, P. K., Carro, M. D., Griffith, G. W., Dagar, S. S., Puniya, M., ... Puniya, A. K. (2014). New aspects and strategies for methane mitigation from ruminants. Applied Microbiology and Biotechnology, 98, 31-34. https://doi.org/10.1007/ s00253-013-5365-0

Martínez, M. E., Ranilla, M. J., Tejido, M. L., Ramos, S., \& Carro, M. D. (2010). The effect of the diet fed to donor sheep on in vitro methane production and ruminal fermentation of diets of variable composition. Animal Feed Science and Technology, 158, 126-135. https://doi. org/10.1016/j.anifeedsci.2010.04.005

Ranilla, M. J., Carro, M. D., López, S., Newbold, J. C., \& Wallace, J. (2001). Influence of $\mathrm{N}$ source on the fermentation of fibre from barley straw and sugarbeet pulp by ruminal micro-organisms in vitro. British Journal of Nutrition, 86, 717-724. https://doi.org/10.1079/ BJN2001475

SAS Institute Inc. (2012). SAS/STAT ${ }^{(\mathbb{B}} 12.2$ User's guide. Cary, NC, USA: SAS Inst Inc.

Tejido, M. L., Ranilla, M. J., García-Martínez, R., \& Carro, M. D. (2005). In vitro microbial growth and rumen fermentation of different 
substrates as affected by the addition of disodium malate. Animal Science, 81, 31-38. https://doi.org/10.1079/ASC42060031

Van Soest, P. J., Robertson, J. B., \& Lewis, B. A. (1991). Methods for dietary fiber, neutral detergent fiber, and nonstarch polysaccharides in relation to animal nutrition. Journal of Dairy Science, 74, 3583-3597. https://doi.org/10.3168/jds.S0022-0302(91)78551-2

Vanegas, J. L., Carro, M. D., Alvir, M. R., \& González, J. (2017). Protection of sunflower seed and sunflower meal protein with malic acid and heat: Effects on in vitro ruminal fermentation and methane production. Journal of the Science of Food and Agriculture, 97, 350-356. https://doi.org/10.1002/jsfa.7743

Vanegas, J. L., González, J., Alvir, M. R., \& Carro, M. D. (2017). Influence of malic acid-heat treatment for protecting sunflower protein against ruminal degradation on in vitro methane production: A comparison with the use of malic acid as an additive. Animal Feed Science and Technology, 228, 123-131. https://doi.org/10.1016/ j.anifeedsci.2017.04.015
Vanegas, J. L., González, J., \& Carro, M. D. (2017). Influence of protein fermentation and carbohydrate source on in vitro methane production. Journal of Animal Physiology and Animal Nutrition, 101, e288-e296. https://doi.org/10.1111/jpn.12604

Wallace, R. J., \& Cotta, M. A. (1988). Metabolism of nitrogen-containing compounds. In P. N. Hobson (Ed.), The Rumen microbial ecosystem (pp. 217-250). London: Elsevier Applied Science.

How to cite this article: Haro AN, Carro MD, de Evan T, González J. Protecting protein against ruminal degradation could contribute to reduced methane production. J Anim Physiol Anim Nutr. 2018;00:1-6. https://doi.org/10.1111/ $\underline{\text { jpn.12973 }}$ 